\title{
International Migrant Remittance and Productivity Growth in Ghana
}

\author{
Yazidu Ustarz \\ Department of Economics and Entrepreneurship Development \\ University for Development Studies, Wa Campus, Ghana \\ uyazidu@uds.edu.gh \\ and \\ Haruna Issahaku \\ Department of Economics and Entrepreneurship Development \\ University for Development Studies, Wa Campus, Ghana \\ iharuna@uds.edu.gh \\ DOI//http://dx.doi.org/10.4314/gjds.v14i2.4
}

\begin{abstract}
The study assessed the relationship between productivity growth and remittance at the macro level. Existing studies have largely focused on the micro level which falls short of revealing how shocks in the economy are transmitted through international remittance. Using time series analysis for data covering the period 1975-2013, the results from trend equation revealed that remittance inflows remained positive and increased modestly over time while economic growth as measured by the growth in labour productivity per person has been fluctuating. Regression results showed that remittance is significantly and negatively related to productivity in Ghana. The study revealed that foreign direct investment, official development assistance and international trade are positively related to productivity. It is recommended that government should make the business environment friendly so as to enhance foreign direct investment and boost trade as these have positive impact on productivity.
\end{abstract}

Keywords: Remittance, Total Factor Productivity, Quantile Regression, Migrants, Ghana

\section{Introduction}

When people move from their place of birth or country of origin to a foreign land, they usually send money or goods back home on periodic basis. The remitted portion is referred to as remittance. International remittances provide a significant share of disposable income for many households in developing countries (Agarwal \& Horowitz, 2002). The United Nations (2013) observed that the world's migrant population increased 
by $50 \%$ (about 77 million) over the period 1990-2013. The report further observed that much of the increase happened over the period 2000-2010 where 4.6 million people migrated annually compared to around 2 million (1990-2000) and 3.6 million for the period 2010 to 2013. Although remittances can be non - monetary, Addison (2004) has explained that it is usually quantified in monetary terms. The periodic remittance of migrants has become a major source of financial flows to Least Developed Countries (Barajas, Chami, Fullenkamp, Gapen, \& Montiel, 2009).

In recent times, remittance has formed a strong financial backbone for beneficiaries in the country of origin. In developing countries, the amount of remittance has been on the ascendancy from about $\$ 20$ billion in 1988 to $\$ 328$ billion in 2007 (UNCTAD, 2011). For many countries, remittances dwarf official international aid. In 2011, for instance, the amount remitted to developing countries was three-fold more than what they received as foreign AID. By the end of 2015, remittance to Developing Countries was $\$ 431.6$ billion. Karagoz (2009) has argued that remittance has a positive effect on the stability and growth of receiving countries. It helps in dealing with credit market failures, income inequality and volatility problems in developing countries. Chami, Fullenkamp and Jahjah (2005) have observed that research interest in migrant remittance is motivated by the fact that if properly channelled into productive investment, remittance has the potential to promote development in the receiving economy.

In Ghana, remittance is considered a critical source of foreign exchange, attracting the attention of policy makers (Acheampong, 2012). Quartey (2006) has observed the critical role played by remittance in the Ghanaian economy due to the increasing growth in the volume of remittance inflows. Remittance inflows are utilised by the beneficiaries for two purposes; consumption smoothening and investment. Given the critical role remittances play in an economy, an examination of its influence on productivity in Ghana is in the right direction. Sam, Boateng and Oppong-Boakwe (2013) looked at the channels of foreign remittance and their utilisation using a sample of beneficiaries within the Kumasi metropolis. They found banks, private companies and individuals to be the main channels of remittance transmission; food, education, church activities and funerals were the areas that remittances were utilised. The study apart from being at the micro level did not employ an econometric model to assess the linkage between remittance and productivity.

Adaawen and Owusu (2013) studied the impact of domestic migrant remittance and its effect on welfare by looking at the movement of people from the northern to southern part of Ghana. They examined earnings of migrants, saving mechanisms, the frequency at which they remit and the transmission mechanism. The findings revealed susu ${ }^{2}$

2 It is a local means of savings where a group of people come together to form an association with the aim of accumulating capital 
and savings and loan companies as the major sources of savings; food and household maintenance were areas amount remitted were put to. Finally, they found saving mechanism, duration and place of stay, income levels and gender to be determinants of the amount, the number of times and the probability of a migrant sending remittance. Like the previous study, the study is a micro one and does not also address the impact of remittance on economic growth not even at the local economy level.

Adams (2006) found remittances from both internal and international sources to reduce poverty levels and its severity in Ghana. The author found the role of international remittance in poverty reduction to be more pronounced than internal remittance. Quartey (2006) looked at remittance and household welfare using data from the Ghana Living Standard Survey round one to four (GLSS 1-4) and found that remittance improves the lives of people in Ghana and its inflow is high during economic shocks, which supports the counter-cyclical argument advanced by the study. Although both Quartey and Adams extensively looked at the subject matter of remittances, their focus was on the micro level rather than the economy as a whole.

The current study departs from previous studies as it seeks to assess the relationship between economic growth and remittance at the macro level. In addition to looking at the macro level, the study relates remittance to productivity rather than GDP growth. This angle of measuring the impact of remittance is very important because it could show whether the reduction in labour supply through migration has positively or negatively benefitted the economy, an information which will not be revealed clearly when the impact is related to just GDP growth.

The study serves as a useful guide for economic policy management and advances the literature on the remittance-productivity nexus. To be able to take full advantage of these inflows, the policy authorities need to know the direction, significance and magnitude of the relationship between remittances and productivity growth.

The rest of the paper is organised as follows: Section two explores evidence from the literature regarding the linkage between remittance and productivity. Section three looks at the methodology employed by the study. Section four presents the findings while section five concludes the study.

\section{Review of Literature}

A lot of arguments have been advanced regarding the impact of international remittance on the development of receiving countries. While remittance levels to developing countries are on the increase, there is no unanimity among academics and policy makers 
on the impact of remittance on economic growth in the long-run (Catrinescu, LeonLedesma, Piracha, \& Quillin, 2006).

El-Sakka and Mcnabb (1999) examined the determinants of migrant remittances at the macro level. They observed that factors both in the host country and the migrant home countries work to affect the flow of remittances. The first factor identified is the level of economic activities in the host country. They argue that the level of economic activities will determine the demand for migrant labour, which will as well impact the wages received by migrants. The level of migrant's earnings will to a large extend define their consumption, and savings and hence, the potential amount that can be remitted. As regards to the country of origin, the determinants of remittance stem from two motives: the desire to support his or her family back home and also the desire to invest or save. The desire to support family back home is typical of developing countries and for that matter Ghana. Migrants, especially those who desire to come back home, at a certain point will remit periodically to build a portfolio back home.

Lucas and Stark (1985) advanced three motives for migrant remittances: Pure Altruism, Pure Self-Interest, and Enlightened Self-Interest. The Altruistic Theory is premised on the belief that the migrant feels obligated to remit as a result of the love and affection he/ she has for the family members back home. This is motivated by the poverty condition back home. They further classified Pure Self-Interest into three; first is the aspiration to inherit. It works under the assumption that inheritance is conditioned on behaviour. A migrant's motives for supporting his or her family, and particularly parents, may encompass the concern to maintain favour in the line of inheritance. Thus the larger the amount remitted the better the migrant's chance of inheritance. A second self-interest motive of the migrant in remitting home may be to invest in assets in the home area and ensure their careful maintenance. Thus, the family becomes a trustworthy agent both in selecting the specific item for purchase and in maintaining the asset on the migrant's behalf. Third, is the desire on the part of the migrant to build social assets if he/she has the intention to return home, which may suffice to promote remittance for investment in fixed assets such as land, livestock, or a house; or for investment in public assets to enhance prestige or political influence.

The Enlightened Self-Interest posits that migrants whose education were sponsored by family members remit home as a means of paying back whatever amount was spent on them during their education. This motive can also be explained within the context of rural-urban migration where the risks of crop failure, price fluctuations, insecurity of land tenancy, livestock diseases, and low agricultural wage may force a household to spread its risks by allocating some members to urban areas through migration. This can be seen as mutually beneficial to both migrant and family to enter a co-insurance 
contract. Remittances as claims would then flow to the family in times of crop failure and to the migrant during spells of unemployment.

Poirine (1997) hypothesised that individual remittance is determined by two factors: informal and implicit loans taken by the individual in the early years of their lives to finance their education so that they become more productive in a sector described as "modern". In the second hypothesis, remittance is seen as an implicit loan by emigrants to their care takers in order to take care of their educational expenditure up to the time they would be ready to migrate. In the final hypothesis, the current generation of emigrants whose education was funded previously, will have to repay the money to the former emigrant who may have now retired in a sector described as "home or village". In addition, the older migrants will have been sending monies home to relatives to build portfolio of properties for them back home.

Imai (2012) argued that remittance could impact economic growth through capital accumulation, growth in labour force and total factor productivity. With capital accumulation, they observed that remittances in addition to increasing the rate of capital accumulation also lowers the cost of capital in the recipient country. They argued a negative relationship between remittance and labour force participation. This is because remittance recipients substitute remittance income for labour income which results in more leisure rather than work. Finally, they assert that, remittance could result in inefficiencies in investment especially where an unskilled recipient makes the decision on behalf of the remitter. Raimi and Ogunjirin (2012) examined the nexus between remittance and growth in Nigeria using multiple regression. They established an inverse relationship between economic growth and remittance. They also established a positive relationship between economic growth and other control variables including foreign private investment and external reserve.

Jawaid and Raza (2012), employing the Johansen and Jeuselius' technique, investigated the relationship between growth and remittances in Korea and China. The cointegration results established a positive and negative long-run relationship between growth and remittances in Korea and China respectively. The result of the causality only shows causality running from remittance to economic growth in both countries. The study, however, used a small sample size (29) which casts some doubt on the findings.

Chami, Fullenkamp, and Jahjah (2005) studied the relationship between remittance and economic growth in a panel study covering 113 countries over the period 1970-1998. They observed that research interest in migrant remittance is motivated by the fact that if properly channelled into productive investment, remittance has the potential to promote development in the receiving economy. Karagoz (2009), in a study of the Turkish economy, using ordinary least square regression, found GDP to be negatively 
related to remittances. El-sakka and Mcnabb (1999) in a study of macroeconomic determinants of remittances in Egypt found the differential between domestic and foreign interest rates to have a negative and significant impact on the inflow of remittances through official channels. Also, the level of real earnings of migrants in the host countries is found to have a significant positive effect on the inflow of remittances. Thus, as the earnings of migrants increase, remittances to the country of origin is expected to increase.

Lim and Morshedb (2015) in examining the motivations behind sending remittances, focused on the question whether the observed increased flow of remittances is the result of increased amounts sent by existing migrants or the result of more migration. Using cross-sectional data for three separate years, they found that home income contractions due to exogenous shocks such as natural disasters do not motivate existing migrants residing abroad to send more remittances. This is contrary to the co-insurance motive as espoused by Lucas and Stark (1985). They also found financial development as proxied by credit to the private sector to be positively related to amount a migrant remits home.

Nsiah and Fayissa (2011) in a study involving 64 countries estimated the impact of remittances on economic growth using annual panel data from 1985-2007. Using Panel Fully Modified OLS techniques, they found remittances to impact economic growth positively in each region (Africa, Latin America, and Asia) and also for all regions as a group. Barguelli, Zaiem and Zmami (2013) in a cross-country study divided the countries into two sub - samples; the first group consists of ten countries known as the largest-remittances-recipient countries in GDP percentage, while the second group consists of eighteen countries known as the largest remittances recipient countries in terms of amounts. The results of the panel data analysis were mixed. While they found remittances to negatively affect economic growth among the first group, the relationship was, however, not significant in the second sample.

Siddique, Selvanathan, and Selvanathan (2010) examined the linkage between remittance and growth in Bangladesh, India and Sri Lanka. Using the Engle and Granger causality test technique, they found a two-way directional causality in Sri Lanka, a unicausal relationship running from remittances to growth in Bangladesh, but did not establish any causality in the case of India. They, however, failed to capture the effect of other control variables including foreign direct investment (FDI), economic openness and aid among others. This is perhaps due to the methodology adopted; the Granger causality cannot identify causality where more than two variables are involved.

Masuduzzaman (2014) in Bangladesh, analysed the role of remittance on economic growth using annual time series data from 1981-2013. The study employed the Johansen estimation technique and found a positive relationship between remittance 
and economic growth in the long run. Exploring further for any causal link between remittance and economic growth, the Granger causality was used. The results showed a uni-directional causality running from growth to remittance. The study, however, failed to show results of the structural break test, making it difficult to utilise the findings in any meaningful way.

In a study in Egypt, Sharaf (2014) employed the ARDL to co-integration to analyse the link between remittance and economic growth. The results show that there exists a longrun relationship between economic growth and remittance. In addition, only a one-way causality running from remittance to output was revealed. The study, however, did not capture other control variables which could impact on the relationship. This can affect the model performance and the results reported. Nyamongo et al. (2012) looked at the role of remittances and financial development on economic growth in Africa within a framework of panel involving 36 countries over the period 1980-2009. They established a significant positive relationship between remittance and economic growth with volatility of remittance been negatively related with economic growth.

Agbola (2013) studied whether human capital constrains the impact of Foreign Direct Investment and remittances on economic growth in Ghana for the period 1965-2008. Using Fully Modified Ordinary Least Squares, the results show that trade openness, human capital, government expenditure, foreign direct investment and remittance were significant and positively associated with economic growth while private investment and unstable political environment were negatively related to economic growth.

Adenutsi (2011) studied the relationship between international migrant remittance, financial development and economic growth covering the period 1987 to 2007 using the Johansen co-integration procedure. In the short-run model international migrantremittance inflows was found to be positively related to economic growth. Other control variables used that were found to be positively and significantly related to economic growth were investment, initial rate of economic growth, government expenditure, human capital development, and inflation. The co-integration results however had only investment and openness as having positive impacts on economic growth in the longrun while inflation and human capital development which were positive in the short-run, rather were negatively influencing growth Ghana. On the test for causality, the study established only a bi-directional causality running from remittances to growth.

Issahaku, Harvey and Abor (2016) found remittances to reduce macroeconomic volatility in developing countries by reducing interest rate and interest rate volatility. In a related study, Issahaku, Abor and Harvey (2017) showed that remittances promote banking financial intermediation in low remittance recipient countries while reducing stock market development in those same countries. On the other hand, the authors found 
remittances to promote stock market development in remittance dependent countries while lowering banking sector development in those same countries.

\section{Methodology}

\section{Empirical Model}

To establish the linkage between productivity and remittance in Ghana, the study followed the model adopted by Hassan and Bhuyan (2013) which is based on the Solow (1957) growth model. In the model, the long-run growth effect is proxied by the rate of growth in Total Factor Productivity (TFP).

The TFP is arrived at through the production function framework which is specified in its general form as:

$$
Y=f(A, L, K)
$$

Where $Y$ captures the real GDP, $L$ represents total labour force, $K$ is the capital stock and $A$ is the total factor productivity (for detailed steps in the estimation of the total factor productivity, see Hassan \& Bhuyan, 2013). By this, the study assumes that the impact of workers' remittances on growth is realised through TFP (Jawaid \& Raza, 2012).

The empirical model is specified below:

$$
\operatorname{TFP}_{t}=\beta_{0}+\beta_{1} \operatorname{Rem}_{t}+\beta_{2} I N F_{t}+\beta_{3} F D I_{t}+\beta_{4} A I D_{t}+\beta_{5} \operatorname{Trade}_{t}+\varepsilon_{t}
$$

Where

TFP is total factor productivity, Rem is remittances as a ratio of GDP, FDI is captured by the net foreign direct investment as a percentage of GDP, AID is measured as foreign aid as a percentage of GDP, Trade is import plus export divided by GDP, which is used as a proxy for economic openness and $\varepsilon_{t}$ is the random error term assumed to be independently, identically distributed (IID).

All variables are in natural logs (so that coefficients could be interpreted as elasticities) and described in table 2. 
Table 1: Definition and measurement of variables

\begin{tabular}{|c|c|c|c|}
\hline Variables & Notation & Measurement & A prior sign \\
\hline Economic growth & TFP & $\begin{array}{l}\text { Real GDP per person employed in } 1990 \\
\text { US } \$ \text { which is converted at Geary Khamis } \\
\text { Purchasing Power Parity }\end{array}$ & \\
\hline Remittances & $R E M$ & $\begin{array}{l}\text { International migrant remittances to } \\
\text { GDP }\end{array}$ & $+/-$ \\
\hline Foreign direct investment & FDI & Foreign direct investment to GDP & + \\
\hline Foreign aid & AID & Foreign aid to GDP & + \\
\hline Openness of the economy & Trade & Import plus export to GDP & + \\
\hline Inflation & INF & $\begin{array}{l}\text { Annual changes in the consumer price } \\
\text { index }\end{array}$ & - \\
\hline
\end{tabular}

Source: Authors' own construct (2016)

\section{Remittance}

The study postulates a positive relationship between productivity and remittance. Out of the total amount remitted, part goes into consumption and the rest are invested in the economy through developmental projects which are expected to impact positively on growth. In addition, the marginal productivity of labour is expected to increase as a result of reduction in labour through migration which is expected to benefit economic growth.

\section{Foreign Direct Investment}

FDI, as argued by Louzi and Abadi (2011) augments the gap in capital stock in developing countries. Technology, managerial skills, as well as entrepreneurial ability, are equally some of the benefits that come through FDI. These are essential for developing countries to fighting poverty. A positive relationship is thus expected between productivity growth and FDI.

\section{Foreign Aid}

The effect of foreign aid in the growth process of least developing countries has attracted much attention in policy circles given its implications in fighting poverty in developing countries. Foreign aid helps to supplement domestic sources in stimulating economic growth (Ekanayake \& Chatrna, 2010). A positive relationship is thus expected. 


\section{Openness of the Economy}

The debate on the impact of exports on economic growth is not new; it was championed by the classical economists led by Adam Smith and David Ricardo. Exports of goods and services represent a critical source of foreign exchange which reduces the pressure on the balance of payments and help create employment opportunities (Shihab, Thikraiat, \& Abdul-Khaliq, 2014). A positive relationship is expected between openness and economic growth.

\section{Inflation}

Inflation erodes savings which is much needed to trigger the necessary economic growth through investment. Persistent increase in prices does not only affect consumption but also cost of production. Thus, a negative relationship between inflation and productivity is envisaged.

\section{Data Sources and types}

The study used data sourced from the World Development Indicators' (WDI) website. The data on various variables span from 1975-2013. Variables covered in the study are remittance, economic growth, import, export, government expenditure, foreign direct investment, foreign aid and government expenditure. Data on the dependent variable, total factor productivity was however sourced from the Conference Board Total Economy Database, 2015.

\section{Discussion of Results}

The section discusses the findings of the study and possible implications of the relationship between economic growth and a set of independent variables including remittance.

\section{Descriptive statistics}

To have a feel of the nature and distribution of the variables used in the study, descriptive statistics were estimated and the results presented in Table 3. 
Table 2: Summary statistics of variables

\begin{tabular}{|l|l|l|l|l|l|}
\hline Variable & Obs & Mean & Std. Dev. & Min. & Max. \\
\hline TFP & 35 & 1.569 & 3.226 & -7.9 & 8 \\
\hline FDI & 35 & 2.506 & 2.962 & -0.070 & 9.512 \\
\hline INF & 35 & 29.663 & 26.324 & 8.727 & 122.874 \\
\hline AID & 35 & 8.040 & 3.710 & 2.696 & 16.338 \\
\hline Trade & 35 & 61.572 & 31.366 & 6.320 & 116.048 \\
\hline REM & 35 & 0.325 & 0.280 & 0.010 & 0.927 \\
\hline
\end{tabular}

Note: The dependent variable is total factor productivity (TFP), REM is remittances/GDP, FDI is net foreign direct investment/GDP, AID is measured as foreign aid/GDP, Trade proxies economic openness and is measured as import plus export to GDP, Inflation (INF) is proxied by annual changes in the consumer price index.

The mean amount of remittance/GDP received over the period is $0.32 \%$. This relatively low figure implies that Ghana has the potential to attract more remittances. Average productivity is about $1.5 \%$, showing that productivity levels in Ghana are quite low. On the average, Ghana received more foreign aid/GDP (8.0\%) than FDI/GDP (2.5\%) over the sample period. This highlights the heavy dependence of the country on donor funds. The average inflation over the period is $29.7 \%$, which highlights Ghana's struggles with price stability. In terms of the standard deviation which is a measure of variation in the distribution of the variable, economic openness appears to be the most volatile of the variables; having about 31\% variation; net remittance has been the most stable. This implies that remittances can cushion the economy during economic downturns.

\section{Trend in Remittance}

To assess movements in economic growth and remittance over time, the trend graph was used as shown in Figure 1. While remittance remained positive and increased modestly over time, economic growth as measured by the growth in labour productivity per person has been fluctuating. The negative portion (1979-1983) is not surprising because it was a period characterised by some adverse developments in the economy. It was a period of coup de'tát and also severe drought that affected production and productivity. The economy, however, began to pick up under the Structural Adjustment Programme (SAP) which saw labour productivity moving into positives, which positive trend has continued till date.

To further validate the positive trend in remittance, a trend equation (Table 4) was used and the results as captured by time coefficient (0.0192161) reinforced the positive slope of remittance with about $49 \%$ variation in remittance over time. 


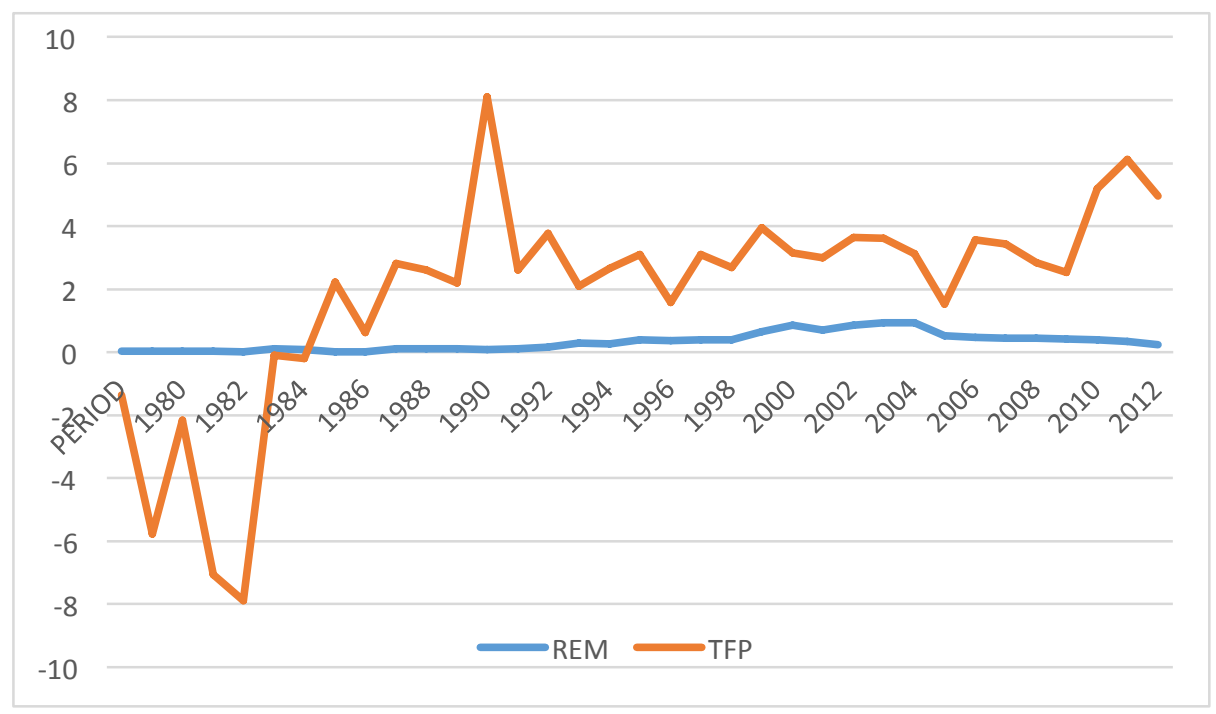

Fig 1:Trend graph of economic growth and remittance

Table 3: Trend equation for remittance

\begin{tabular}{|l|l|l|l|l|}
\hline Variable & Coefficient & Probability & R-squared & Trend \\
\hline YEAR & 0.019 & 0.000 & 0.494 & Increasing \\
\hline & & & & \\
\hline
\end{tabular}

\section{Unit-root Test}

Since the study is employing time-series data, a key requirement in preventing spurious results is to establish whether the data is stationary or not.

The Augmented Dicker-Fuller test was estimated at 5\% (-3.576) critical level with three lags automatically selected based on AIC. The results are presented in Table 5 .

Table 4: Results of ADF-test for Unit-root

\begin{tabular}{|l|l|l|}
\hline Variable & Test-statistic & MacKinnon approximate p-value. \\
\hline TFP & -2.793 & 0.200 \\
\hline FDI & -2.397 & 0.381 \\
\hline INF & -3.127 & 0.100 \\
\hline AID & -1.553 & 0.810 \\
\hline Trade & -2.015 & 0.593 \\
\hline REM & -0.764 & 0.969 \\
\hline
\end{tabular}


Note: The dependent variable is total factor productivity (TFP), REM is remittances/GDP, FDI is net foreign direct investment/GDP, AID is measured as foreign aid/GDP, Trade proxies economic openness and is measured as import plus export to GDP, Inflation (INF) is proxied by annual changes in the consumer price index.

The results show that the critical value of 3.576 is more than all the test values for all the variables. Also, as indicated by the probability value, none of the test-value is significant. Thus, we fail to reject the null-hypothesis of no unit-root. Once it is established that all variables were stationary, the OLS estimation technique was used and the results presented in Table 6.

\section{Regression Results}

To establish the relationship between economic growth and a set of dependent variables, the OLS model was used and the result presented in Table 6.

Table 5: Regression results with economic growth as the dependent variable

\begin{tabular}{|l|l|l|}
\hline Variable & Coefficient & Std. Error \\
\hline INF & & \\
\hline FDI & $-0.028^{*}$ & 0.015 \\
\hline AID & $0.369^{* *}$ & 0.170 \\
\hline REM & $0.470^{* * *}$ & 0.128 \\
\hline Trade & $-7.544^{* * *}$ & 2.219 \\
\hline C & $0.070^{* * *}$ & 0.024 \\
\hline Diagnostics & $-4.123^{* * *}$ & 1.393 \\
\hline R-squared & & \\
\hline Adjusted R-squared & & 0.728536 \\
\hline F-statistic & & 0.681731 \\
\hline Prob (F-statistic) & & $15 \cdot 56560$ \\
\hline Jarque-Bera Probability & & 0.000000 \\
\hline Probability of Breusch-Godfrey Serial Correlation LM Test: & & 0.717432 \\
\hline Heteroscedasticity Test: Breusch-Pagan-Godfrey & & 0.417500 \\
\hline Nte: & & 0.05250 \\
\hline
\end{tabular}

Note: The dependent variable is economic growth captured as total factor productivity (TFP), REM is remittances/GDP, FDI is net foreign direct investment/GDP, AID is measured as foreign aid/GDP, Trade proxies economic openness and is measured as import plus export to GDP, Inflation (INF) is proxied by annual changes in the consumer price index. ${ }^{*},{ }^{* *},{ }^{* *}$ represent significant levels at $10 \%, 5 \%$ and $1 \%$ respectively. The dignostic tests are: (1) R-squared statistic, (2) Adjusted R-squared statistic, (3) F-statistic of joint significance of coefficients, (4) Breusch-Godfrey test for serial correlation of which the null hypothesis is that there is no autocorrelation in the errors and (5) Breusch-Pagan-Godfrey test for heteroskedasticity of which the null hypothesis is that the error term is homoscedastic. 
The model diagnostics show that the model performed very well and explains over 68\% of the variations in the dependent variable as represented by the adjusted R-squared. The model also passed the test of normality, serial correlation and heteroscedasticity which signifies that the estimated coefficients are unbiased and efficient.

From the regression results, all variables used in the estimation appear to be significantly related to economic growth. Inflation is negatively related to economic growth; a percentage increase in inflation leads to about $0.02 \%$ reduction in economic growth. This makes sense because inflation erodes savings which will negatively affect investment and consequently economic growth.

Foreign direct investment also shows a significant and positive relationship with economic growth. This is not surprising because most developing countries rely on FDI to stimulate economic growth due to the long-standing problem of inadequate capital for investment. A percentage increase in FDI (financial openness), leads to about $0.4 \%$ increase in economic growth.

Official Development Assistance also as expected shows a positive and significant relationship with economic growth even over - performing FDI in terms of its impact on economic growth. It shows that a percentage increase in AID leads to about $0.47 \%$ increase in economic growth.

Turning to the variable of interest, remittance appear to be significantly and negatively related to economic growth. It reveals that a percentage increase in remittance leads to a reduction in economic growth by $7.5 \%$. This shows that, in spite of increasing flow of remittance into the economy, the economy has not benefited significantly. This could possibly be explained within the context of the 'Dutch disease' where remittance inflows lead to appreciation of the local currency leading to a loss of international competitiveness (Acosta, Lartey \& Mandelman. 2009.) Again, remittances are mostly expended on consumption and leisure and sometimes lead to a reduction in labour supply (Imai, 2012). Another plausible explanation is that skilled labour force often leave the shores of Ghana for greener pastures which could lead to a decline in the productivity of labour in the domestic economy, especially if the amount of remittance sent home does not yield benefits commensurate with the loss of skilled labour.

Our finding that remittance is negatively related to economic growth is consistent with the findings of Raimi and Ogunjirin (2012), Karagoz (2009). It is however, inconsistent with the finding of Jawaid and Raza (2012), Nsiah and Fayissa (2011). The result also indicates that Ghana modestly benefited from international trade as the variable shows a significantly positive relationship with economic growth. Thus a percentage increase in trade leads to $0.06 \%$ increase in economic growth. 


\section{Stepwise Regression Results}

A stepwise regression was estimated to show the strength of the relationship between productivity and remittance as more control variables are added to the model. The results are presented in Table 7.

Table 6: Regression with labour productivity as dependent variable

\begin{tabular}{|l|l|l|l|l|l|}
\hline Variable & R1 & R2 & $R_{3}$ & $R_{4}$ & $R_{5}$ \\
\hline REM & $4.316^{* *}$ & 1.840 & 1.494 & -2.889 & $-7.544^{* * *}$ \\
\hline INF & & $-0.067^{* * *}$ & $-0.060^{* *}$ & $-0.037^{*}$ & $-0.028^{*}$ \\
\hline FDI & & & 0.185 & $0.620^{* *}$ & $0.3692^{* *}$ \\
\hline AID & & & & $0.5988^{* * *}$ & $0.4696^{* * *}$ \\
\hline Trade & & & & & $0.0696^{* * *}$ \\
\hline Constant & 0.167 & $2.967^{* * *}$ & $2.410^{* *}$ & $-2.758^{*}$ & $-4.123^{* * *}$ \\
\hline Diagnostics & & & & & \\
\hline R-squared & 0.141 & 0.396 & 0.419 & 0.651 & 0.729 \\
\hline Adjusted-R & 0.114 & 0.358 & 0.363 & 0.605 & 0.681 \\
\hline F-statistic & 5.40 & 10.49 & 7.46 & 14.03 & 15.566 \\
\hline Prob-F & 0.026 & 0.000 & 0.000 & 0.000 & 0.000 \\
\hline Normality & 0.032 & 0.000 & 0.000 & 0.006 & 0.717 \\
\hline SerCorrela & 0.000 & 0.015 & 0.039 & 0.274 & 0.653 \\
\hline Hetroscedas & 0.003 & 0.013 & 0.013 & 0.245 & 0.103 \\
\hline
\end{tabular}

Note: The dependent variable is economic growth captured as total factor productivity (TFP), REM is remittances/GDP, FDI is net foreign direct investment/GDP, AID is measured as foreign aid/GDP, Trade proxies economic openness and is measured as import plus export to GDP, Inflation (INF) is proxied by annual changes in the consumer price index. ${ }^{*},{ }^{* *},{ }^{* * *}$ represents significant levels at $10 \%, 5 \%$ and $1 \%$ respectively. The diagnostic tests are: (1) R-squared statistic, (2) Adjusted R-squared statistic, (3) F-statistic of joint significance of coefficients, (4) Jarque-Bera test for normality, (5) Breusch-Godfrey test for serial correlation of which the null hypothesis is that there is no autocorrelation in the errors and (6) Breusch-Pagan-Godfrey test for heteroskedasticity of which the null hypothesis is that the error term is homoscedastic.

Evidence of the relationship between productivity and remittance is mixed from the stepwise regression in Table 7. Thus, from R1, there exist a significantly positive relationship between productivity and remittance. It is same for both $\mathrm{R}_{2}$ and $\mathrm{R}_{3}$ except that the relationships are not significant in $\mathrm{R}_{2}$ and $\mathrm{R}_{3}$. In both $\mathrm{R}_{4}$ and $\mathrm{R}_{5}$, the relationships became negative but only significant in $\mathrm{R} 5$. It is clear that, as more control variables are added, the impact of remittance on productivity appears to be negative. It goes to confirm that, the relationship between productivity and remittance when looked in isolation, could lead to a misleading conclusion. Further, judging by the consistent increase in the adjusted- $\mathrm{R}$ - squared each time a variable is added, it confirms that these 
controlled variables are important when determining the impact of remittance on productivity.

Trade, aid and foreign direct investment were found to be positively related to productivity while inflation is negatively related to productivity, which are all in line with the a prior signs. Inflation can negatively affect productivity through increase in cost of production. To deal with high production cost, both government and private firms result to cutting down output and hence, reduction in growth. The negative relationship so established is intuitive. Trade has been established in literature as a major source of foreign exchange which is needed to finance economic activities and thus, growth. Also, aid has long been a means of financing developmental activities in developing countries, hence the established positive relationship between productivity and aid only reinforces this argument. Finally, foreign direct investment complements domestic private investment in developing countries where capital accumulation has been a major set-back to economic growth. It is therefore not surprising that the study found a positive relationship between productivity and foreign direct investment.

\section{Further Check for Robustness}

To validate further the established negative relationship between productivity and remittance from Table 7, a quantile regression is used to see whether the direction of the relationship varies with time or not.

Table 7: Quantile regression (Economic growth as dependent variable)

\begin{tabular}{|l|l|l|l|l|}
\hline \multirow{2}{*}{ Variables } & \multirow{2}{*}{ OLS regression } & \multicolumn{2}{|l|}{ Quantile regression } \\
\cline { 3 - 5 } & & 0.25 Quantile & 0.50 Quantile & 0.75 Quantile \\
\hline REM & $-7.544^{* * *}$ & -5.568 & $-6.654^{* *}$ & $-5.595^{* *}$ \\
\hline INF & $-0.028^{*}$ & $0.061^{* *}$ & -0.022 & -0.021 \\
\hline FDI & $0.369^{* *}$ & 0.257 & 0.290 & 0.148 \\
\hline AID & $0.470^{* * *}$ & 0.310 & $0.270^{*}$ & $0.195^{*}$ \\
\hline Trade & $0.070^{* * *}$ & 0.049 & $0.066^{* *}$ & $0.064^{* *}$ \\
\hline Constant & $-4.123^{* * *}$ & -1.744 & -2.265 & -0.937 \\
\hline & & & & \\
\hline No. obs. & 35 & & & \\
\hline Psuedo-R & 0.681731 & 0.5473 & 0.3994 & 0.4240 \\
\hline
\end{tabular}

Note: The dependent variable is economic growth captured as total factor productivity (TFP), REM is remittances/GDP, FDI is net foreign direct investment/GDP, AID is measured as foreign aid/GDP, Trade proxies economic openness and is measured as import plus export to GDP, Inflation (INF) is proxied by annual changes in the consumer price index. ${ }^{*},{ }^{* *},{ }^{* *}$ represents significant levels at $10 \%, 5 \%$ and $1 \%$ respectively. 
The results shown in Table 8 indicate that there exists a negative relationship between remittance and productivity throughout the quantiles. Significantly, the coefficient increased from the $25^{\text {th }}$ quantile up to about $7.6 \%$ in the $100^{\text {th }}$ quantile. This shows that the impact of remittance on productivity increases with time.

Apart from remittance, the other variables in the model also passed the test of robustness. Net foreign direct investment maintained its positive effect on productivity throughout the quintiles although not significant as in the OLS regression model. Net official development assistant equally maintained positive effect on productivity throughout though only significant in the $50^{\text {th }}$ quantile. Inflation largely maintained the negative effect on productivity with the exception of the $25^{\text {th }}$ quantile. Trade exhibited a positive effect on productivity throughout the various quantiles.

\section{Conclusion and Policy Recommendation}

The study sought to establish the effect of remittance on economic growth in Ghana from 1979-2013 using both trend and regression analysis. Remittance was found to be negatively related to productivity growth in Ghana. The finding means that though the economy benefits through the money migrants remit, the net effect of migration on the economy is negative. This undesirable result may be related to the moral hazard problem associated with remittances where an increase in remittance inflows leads to an increase in the consumption of nondurable goods and a reduction in labour supply. To enhance productivity, the study recommends that government should make the business environment friendly so as to enhance foreign direct investment as this has positive impact on productivity. Measures such as easy registration processes as well as transparency in the registration systems, good governance practices can also help in attracting the much needed aid to help finance growth. Crafting policies which regulate the movement of skilled labour could enhance productivity in the economy. 


\section{References}

Acheampong, J. K. (2012). Partnership for economic growth and development: remittances and FDI (online). Available at: content/uploads/2012/10/ joseph_acheampong.pdf. Accessed 25th May, 2016.

Acosta, P.A., Lartey, E.K.K. and Mandelman, F.S. (2009). Remittances and the Dutch disease. Journal of International Economics, 79(1), pp. 102-116.

Adaawen, S. A. and Owusu, B. (2013). North-South migration and remittance in Ghana. African Review of Economics and Finance, 5 (1), pp. 29-45.

Adams, R.H. (2006). Remittances and poverty in Ghana, World Bank Policy Research Working Paper 3838, February. Washington, D.C.: World Bank.

Addison, E. K.Y. (2004). The macro-economic impact of remittances. Paper presented at the Conference on Migration and Development, Accra (1416 September).

Agarwal, R., and Horowitz, A.W. (2002). Are international remittances altruism or insurance? Evidence from Guyana Using Multiple-Migrant Households, World Development, 30(11), pp. 2033-2044.

Barajas, A., Chami, R., Fullenkamp, C., Gapen, M. and Montiel, P. (2009). "Do workers' remittances promote economic growth?" IMF Working Paper WP o9/153. Washington, D.C.: International Monetary Fund.

Barguelli, A., Zaiem, M.H. and Zmami, M. (2013). Remittances, education and economic growth, a panel data analysis, Journal of Business Studies Quarterly, 4(3), pp. 129-139.

Catrinescu, N., Leon-Ledesma, M., Piracha, M. and Quillin, B. (2006). Remittances, institutions and economic growth. IZA Discussion Paper No. 2139.

Chami, R., Fullenkamp, C. and Jahjah, S. (2005). Are immigrant remittance flows a source of capital for development? IMF Staff Papers, 52(1), pp. 55-81.

Ekanayake, E.M. and Chatrna, D. (2010). The effect of foreign aid on economic growth in developing countries. Journal of International Business and Cultural Studies, 3(2), pp. 1-13.

Elbeydi, K.R.M., Abdulbaset, M. H. and Vladimir, G. (2010). The relationship between export and economic growth in Libya Arab Jamahiriya. Theoretical and Applied Economics, 17(1), pp.69-76.

El-Sakka, M.I.T. and Mcnabb, R. (1999). The macroeconomic determinants of emigrant remittances. World Development, 27(8), pp. 1493-1502. 
Hassan, G.M. and. Bhuyan, S.M. (2013). Growth effects of remittances: Is there a u-shaped relationship? Working Paper in Economics 16/13.

Imai, K. S., Gaiha, R., Ali, A. and Kaicker, N. (2012). Remittances, growth and poverty. International Fund for Agricultural Development.

Issahaku, H., Abor, J.Y., and Harvey, S.K. (2017). Remittances, banks and stock markets: Panel evidence from developing countries. Research in International Business and Finance, Retrieved from: http://dx.doi.org/10.1016/j.ribaf.2017.07.080.

Issahaku, H., Harvey, S.K. and Abor, J.Y. (2016). Does development finance pose an additional risk to monetary policy? Review of Development Finance, 6(2016), pp. 91-104.

Jawaid, S.T. and Raza, S. R. (2012). Workers' remittances and economic growth in China and Korea: an empirical analysis, Journal of Chinese Economic and Foreign Trade Studies, 5(3), pp. 185-193.

Lima, S.A.K.M. and Mahbub, M. (2015). International migration, migrant stock, and remittances: Re-examining the motivations to remit, The Quarterly Review of Economics and Finance, 57, pp. 101-115.

Louzi, B.M. and Abadi, A. (2011). The impact of foreign direct investment on economic growth in Jordan. IJRRAS, pp. 253-258.

Lucas, R.E. B. and Stark, O. (1985). Motivations to remit: evidence from Botswana. Journal of Political Economy, 93, pp. 901-918.

Masuduzzaman, M. (2014). Workers' remittance inflow, financial development and economic growth: A study on Bangladesh, International Journal of Economics and Finance, 6(8), pp. 247-267.

Mesbah, F.S. (2014). The Remittances-Output Nexus: Empirical Evidence from Egypt (online). Available at: http://dx.doi.org/10.1155/2014/965240. Accessed 2oth March, 2016.

Nsiah, C. and Fayissa, B. (2013). Remittances and economic Growth in Africa, Asia, and Latin American-Caribbean Countries: A panel unit-root and panel co-integration analysis. Journal of Economics and Finance, 37(3), pp. 424-441.

Poirine, B. (1997). A theory of remittances as an implicit family loan arrangement. World Development, 25(4), pp. 589-611.

Quartey, P. (2006). The impact of migrant remittances on household welfare in Ghana. The African Economic Research Consortium, Nairobi, Kenya. 
Raimi, L. and Ogunjirin, O.D. (2012). Fast-tracking sustainable economic growth and development in Nigeria through international migration and remittances. Emerald Group Publishing Limited, 28(3), pp. 209-219.

Ratha, D. (2013). The impact of remittances on economic growth and poverty reduction, policy brief no.8, Migration Polity Institute, Washington, D.C.: World Bank.

Sam, G., Boateng, F. and Oppong-Boakwe, P. (2013). Remittances from abroad: The Ghanaian household perspective. International Journal of Business and Social Science, 4(1), pp. 164-170.

Sharaf, M.F. (2014). The remittances-output nexus: Empirical evidence from Egypt, Economics Research International (online). Available at: http://dx.doi.org/10. 1155/2014/965240. Accessed 2oth May, 2016.

Shihab, R.A., Thikraiat, S. and Abdul-Khaliq, S. (2014). The causal relationship between exports and economic growth in Jordan International Journal of Business and Social Science, 5(3), pp. 302-308.

Siddique, A., Selvanathan, E.A. and Selvanathan, S. (2010). Remittances and economic growth: Empirical evidence from Bangladesh, India and Sri Lanka Discussion Paper 10.27, University of Western Australia.

United Nations (2013). World migration in figures, a joint contribution by UN-DESA and the OECD to the United Nations High-Level Dialogue on Migration and Development (online). Available at: https://www.oecd.org/els/mig/World-Migration-in-Figures. pdf. Accessed 21st May, 2016.

United Nations Conference on Trade and Development (2011). Impact of remittances on poverty in developing countries (online). Available at: http://unctad.org/ en/docs / ditctncd20108en.pdf. Accessed 20th May, 2016. 